\title{
The Kampala Convention and the Protection of Persons Internally Displaced by Harmful Practices in Africa
}

\author{
Romola Adeola* \\ University of Pretoria, South Africa \\ romola.adeola@gmail.com
}

\begin{abstract}
Arguably the least discussed root cause of internal displacement, harmful practices are a prevalent concern in many African societies. The explicit mention of harmful practices is one of the many innovations of the Kampala Convention and reinforce its forward-looking, context-specific focus on Africa. This article argues that the convention has an absolute prohibition of harmful practices. This is an important starting point from which to discuss the content of states' obligation to set measures for preventing harmful practices. However, in the event that displacement occurs due to these practices, it is important that protection, humanitarian assistance and durable solutions are provided. This article argues that states must set measures for ensuring that non-state actors are held accountable in the event that they orchestrate harmful practices. In fostering compliance, this article argues that there is an important role for institutions beyond the state, particularly those emphasized under article 14 of the convention.
\end{abstract}

\section{Keywords}

Internal displacement, internally displaced persons, harmful practices, Kampala Convention, Africa

\section{INTRODUCTION}

Extensive research on the protection and assistance of internally displaced persons (IDPs) has emerged over the last decade. ${ }^{1}$ Scholars have underscored the

Coordinator, Global Engagement Network on Internal Displacement in Africa (GENIDA); fellow, Centre for Human Rights, Faculty of Law, University of Pretoria, South Africa. The author acknowledges the support from GENIDA (EP/T003227/1) and the Interdisciplinary Network on Internal Displacement, Conflict and Protection (AH/T005351/1) projects funded by the UK Research and Innovation Global Challenges Research Fund.

1 For example: S Ojeda "The Kampala Convention on Internally Displaced Persons: Some international humanitarian law aspects" (2010) 29/3 Refugee Survey Quarterly 58; FZ Guistiniani "New hopes and challenges for the protection of IDPs in Africa: The Kampala Convention for the Protection and Assistance of Internally Displaced Persons 
importance of the African Union (AU) Convention for the Protection and Assistance of Internally Displaced Persons in Africa (Kampala Convention) ${ }^{2}$ and emphasized the significance of this framework in addressing internal displacement in Africa. That the Kampala Convention has shaped regional understanding on internal displacement is evident, not only in scholarly writing but also in norms and policy frameworks at various levels of governance in Africa. Indeed, it has emerged as a beacon of protection and assistance for IDPs, with broad acceptance and legitimation as a fundamental norm on internal displacement. Many of these works have examined the issue of internal displacement from the perspective of other root causes, such as conflict and development projects. This article examines the provisions of the Kampala Convention in respect of harmful practices.

To begin, it is relevant to examine the issue of harmful practices as an internal displacement concern. In this regard, the first section of the article considers harmful practices as a root cause of internal displacement, drawing on evidence that reflects that this root cause is a concern requiring attention. The article then analyses protection for persons internally displaced by harmful practices through the lens of the Kampala Convention, drawing on its normative provisions. Within the context of the institutional mechanism saddled with implementing the Kampala Convention, the article examines how protection and assistance for IDPs within the context of this root cause of internal displacement may be advanced.

\section{HARMFUL PRACTICES AS A ROOT CAUSE OF INTERNAL DISPLACEMENT}

Article 4(4)(e) of the Kampala Convention specifically recognizes harmful practices as a root cause of internal displacement. This is one of the important areas in which the Kampala Convention builds on existing frameworks on internal displacement, particularly the UN Guiding Principles on Internal Displacement (Guiding Principles) and the Protocol on the Protection and Assistance of Internally Displaced Persons in the Great Lakes Region. ${ }^{3}$ In a

contd

in Africa" (2011) 39/2 Denver Journal of International Law and Policy 347; MT Maru The Kampala Convention and Its Contribution to International Law: Legal Analyses and Interpretations of the African Union Convention for the Protection and Assistance of Internally Displaced Persons (2014, Eleven Publishing); AM Abebe The Emerging Law on Forced Migration in Africa: Development and Implementation of the Kampala Convention on Internal Displacement (2016, Routledge).

2 Adopted in Kampala, Uganda, 23 October 2009.

3 UN Commission on Human Rights, addendum "Guiding Principles on Internal Displacement" (report of the representative of the Secretary-General, Mr Francis M Deng, submitted pursuant to UN Commission on Human Rights res 1997/39), UN doc E/CN.4/1998/53/Add.2 (11 February 1998); Protocol on the Protection and Assistance to Internally Displaced Persons, adopted by the International Conference on the Great Lakes (2006). 
joint general comment by the Committee on the Elimination of Discrimination against Women (CEDAW) and Committee on the Rights of the Child (CRC), harmful practices are described as:

"[P]ersistent practices and forms of behaviour that are grounded in discrimination on the basis of, among other things, sex, gender and age, in addition to multiple and / or intersecting forms of discrimination that often involve violence and cause physical and / or psychological harm or suffering. The harm that such practices cause to the victims surpasses the immediate physical and mental consequences and often has the purpose or effect of impairing the recognition, enjoyment and exercise of the human rights and fundamental freedoms of women and children. There is also a negative impact on their dignity, physical, psychosocial and moral integrity and development, participation, health, education and economic and social status." ${ }^{4}$

This description coheres with similar explanations of harmful practice in the African regional context. For instance, article $1(\mathrm{~g})$ of the Protocol to the African Charter on Human and Peoples' Rights on the Rights of Women in Africa (Maputo Protocol) defines harmful practices as: "all behaviour, attitudes and / or practices which negatively affect the fundamental rights of women and girls, such as their right to life, health, dignity, education and physical integrity". 5 The Kampala Convention reflects the Maputo Protocol in its definition of harmful practices, although without specific reference to gender, for a broader application within the context of internal displacement. Explicitly, article 1(j) of the Kampala Convention defines harmful practices as: "all behaviour, attitudes and / or practices which negatively affect the fundamental rights of persons, such as but not limited to their right to life, health, dignity, education, mental and physical integrity and education".

Harmful practices are prevalent forms of violence, manifest in a plethora of ways across several societies and with long-term impacts. Harmful practices are practices often done, "for cultural or socio-conventional motives and which have harmful consequences on the health and the rights of the victims". ${ }^{6}$ Grounded in societal traditions and cultures, harmful practices particularly affect women and children and reinforce existing discriminatory patterns and patriarchal orders that victimize these categories and exclude

4 Joint General Recommendation No 31 of CEDAW / General Comment No 18 of the CRC on Harmful Practices (2014), para 15.

5 See Protocol to the African Charter on Human and Peoples' Rights on the Rights of Women in Africa (2003), art $1(\mathrm{~g})$.

6 UN Division for the Advancement of Women "Harmful traditional practices against women and legislation" (expert paper prepared by Dr Morissanda Kouyaté, director of operations, Inter-African Committee on Traditional Practices Affecting the Health of Women and Children, Addis Ababa, Ethiopia, 11 May 2009), UN doc EGM/GPLHP/2009/EP.07 at 2. 
them from participating in the advancement of their rights and fundamental freedoms. ${ }^{7}$

These practices are "consequences of the value placed on women and the girl child by society. They persist in an environment where women and the girl child have unequal access to education, wealth, health and employment". Across many African societies, these practices are often a consequence of patriarchal orderings, socio-cultural belief systems, poverty and gender inequalities. While some practices are linked to one of these factors, there are others that stem from an interplay of these causes. For instance, the practice of child marriage and female genital mutilation, across many contexts, is significantly linked to an interplay between these factors. For instance, in Niger, one of the poorest countries in the world ${ }^{9}$ and a country with a high prevalence of child marriage, families marry off their girls as a way of lessening the socioeconomic burden on the family. Given the patriarchal construction of the family, there is often limited agency on the part of the girls in influencing the decision. ${ }^{10}$ Moreover, gender roles are quite set, with the primary role of girls and eventual child brides being to engage in domestic tasks and meet the expectations of their spouses and in-laws. In a 2019 study on Child Marriage, Fertility and Family Planning in Niger, for instance, it was observed that:

“[A]lmost all husbands - 91 percent - agreed giving more rights to women meant men could lose out, and 86 percent agreed women are too emotional to be leaders. This stark contrast suggests that while husbands may recognize the existence of gender inequalities in their society, they may perceive personal consequences to making these rights more equal between men and women". ${ }^{11}$

These perceptions and attitudinal dispositions towards women and girls reinforce marginalization and discrimination and, as such, affect the agency of women and girls in decisions concerning their lives. However, these negative constructions of gender roles reinforced by patriarchy also affect men. Greene et al, argue, for instance, that a "dominant, risk-taking sexuality that

7 B Winter, D Thompson and S Jeffreys "The UN approach to harmful traditional practices" (2002) 4/1 International Feminist Journal of Politics 72; Gaining Ground: A Tool for Advancing Reproductive Rights Law Reform (2006, Center for Reproductive Rights) at 55; J Cottingham and E Kismodi "Protecting girls and women from harmful practices affecting their health: Are we making progress?” (2009) 106/2 International Journal of Gynecology and Obstetrics 128.

8 "Harmful traditional practices affecting the health of women and children" (UN fact sheet no 23, 1995).

9 Oxfam International "Niger", available at: < https://www.oxfam.org/en/what-we-do/ countries/niger $>$ (last accessed 15 January 2021).

10 Girls Not Brides "Niger", available at: <https://www.girlsnotbrides.org/childmarriage/niger/> (last accessed 15 January 2021).

11 E Spindler et al Child Marriage, Fertility and Family Planning in Niger: Results From a Study Inspired by the International Men and Gender Equality Survey (IMAGES) (2019, Promundo-US) at 65, available at: <https://promundoglobal.org/wp-content/uploads/ 2019/02/IMAGES-NIGER-Full-Report-Web-006.pdf> (last accessed 15 January 2021). 
does not permit desire or input on the part of women not only disempowers women and reinforces an often disrespectful narrative about them, it restricts men from expressing their sexuality in ways that do not conform to macho ideals". ${ }^{12}$ Evidently, re-calibrating the logic on power and addressing structural inequalities is imperative to building healthy societal relations and advancing the development of both genders. Integral to addressing these practices is the need to tackle these causes through an evidence-based analysis of various societal contexts.

Given the pluralistic nature of societies across the continent, with formal and informal systems of law, these practices unveil a tension, with consequences that are far-reaching for democratic norms and human rights commitments. Given that these practices call into question states' human rights obligations, explicit prohibitions are crucial. Moreover, there is a consensus that ending these practices and their manifest forms is integral to furthering the regional agenda of transformation. Indeed, this has played out in some initiatives at regional level. ${ }^{13}$ However, a notable gap in the discussion is the displacement dimension of these practices. As such, even while studies have begun to draw attention to the prevalence of these practices across Africa, ${ }^{14}$ and indeed recognize the need to address them, a connection is rarely drawn to the issue of internal displacement, even though the Kampala Convention is explicit on this recognition. However, understanding the dimensions through which this root cause of internal displacement manifests, and developing normative responses accordingly, is crucial to finding durable solutions to the various root causes of internal displacement in Africa. This is also in keeping with the objective of the Kampala Convention to serve as a "legal framework for preventing internal displacement, and protecting and assisting internally displaced persons in Africa". ${ }^{15}$

Evidence of the nexus between harmful practices and internal displacement has emerged in the context of female genital mutilation / cutting (FGM/C). Across 29 African countries, this practice has emerged as a pertinent concern, with high prevalence rates in countries such as Ethiopia, Egypt and Sierra Leone. ${ }^{16}$ Rooted in belief systems that reinforce patriarchy and perpetuate

12 ME Greene et al "The centrality of sexuality for understanding child, early and forced marriage" (2018, Greenworks) at 16, available at: <https://ajws.org/wp-content/uploads /2018/05/centrality_of_sex_final.pdf> (last accessed 15 January 2021).

13 See AU "Campaign to end child marriage in Africa: Call to action" (undated) (copy on file with the author).

14 See generally CAA Packer Using Human Rights to Change Tradition: Traditional Practices Harmful to Women's Reproductive Health in Sub-Saharan Africa (2002, Intersentia); CA Hingston and TL Asuelime "Violated by heritage: African women and harmful traditional practices" (2019) 8/1 Journal of Gender, Information and Development in Africa 51.

15 Kampala Convention, art 2(b).

16 The Law and FGM: An Overview of 28 African Countries (2018, Thomas Reuters Foundation and 28 Too Many) at 11, 31 and 36; "FGM and the law around the world" (19 June 2019) Equality Now. 
inequality, FGM/C is practised on young girls as they attain puberty and is often precipitated by the rhetoric that such a practice is integral to their acceptance within society and, in some societies, as a marriage ritual. ${ }^{17}$ The practice of FGM/C on girls in some societies determines value, sometimes in a monetary context, reinforcing the objectification of the girl-child and, invariably, placing a limit on the capabilities of these groups within the society. In some cultures, the benefits of social acceptance make women and girls less resistant to this practice. However, FGM/C has serious detrimental impacts, not least on health and development. In various countries, including Kenya and Tanzania, evidence has emerged of girls fleeing their homes and places of habitual residence to avoid FGM/C. ${ }^{18}$ This is often followed by dire consequences, including ostracization and physical harm to the girls.

Evidence of the connection has also emerged in the context of child marriage, which is a concern in many parts of Africa. Global estimates suggest that, by 2050, sub-Saharan Africa will have the highest prevalence of child marriage, surpassing South Asia if trends are not reversed. ${ }^{19}$ With prevalence rates as high as 76 per cent in Niger and 68 per cent in Central African Republic, ${ }^{20}$ child marriage is a widespread harmful practice across many African societies, with exacerbated risks to girls in conflict regions. This practice is rooted in culture and traditions of patriarchy and, in some instances, perpetuated by poverty. In this context, girls are commodified and used as a means of lifting their families out of financial difficulties. Moreover, there is the argument that marrying girls early prevents promiscuity, ${ }^{21}$ which partly accounts for its prevalence in some conservative societies. This argument is also advanced in some societies in Africa where FGM/C is practised. ${ }^{22}$ However, this practice has devastating effects on the rights of women and girls. Aside from the fact that it affects children's rights to education, equality and development, it also has dire health implications on sexual and reproductive health.

17 O Khazan "Why some women choose to get circumcised" (8 April 2015) The Atlantic.

18 R Sanghani "Meet the amazing woman running a safe house for girls fleeing FGM" (2 April 2015) The Telegraph; G Portenier "In the name of your daughter" (documentary film, 2016), available at: <https://inthenameofyourdaughterfilm.com> (last accessed 20 January 2021); "The Kenyan girls who fled their families to escape FGM" (14 July 2016) BBC News; L Rendleman Women Like Us: Together Changing the World (2017, First Edition Design Publishing, Inc) at 97.

19 Ending Child Marriage: Progress and Prospects (2014, UNICEF) at 7.

20 V Egbetayo and YK Muhia "Child marriage and the education crisis in Africa: Where do we go from here?” (14 January 2020) Global Partnership for Education.

21 "Achieving key results for children in Niger (KR4C \# 6): Ending child marriage" (UNICEF Niger issue brief, May 2018) at 2. See also NM Nour "Health consequences of child marriage in Africa" (2006) 12/1 Emerging Infectious Diseases 1644 at 1645.

22 "Country profile: FGM in Somalia and Somaliland" (March 2019, 28 Too Many) at 17, available at: <https:/www.28toomany.org/static/media/uploads/Country\%20Research \%20and\%20Resources/SomaliaSomaliland/country_profile_somalia_and_somaliland_v1_ (march_2019).pdf> (last accessed 15 January 2021). 
Evidence of girls fleeing child marriage has emerged in countries such as Kenya, Uganda and Nigeria. ${ }^{23}$

Another prevalent harmful practice relates to breast ironing, which is prevalent in parts of western and central Africa. ${ }^{24}$ However, much of the discussion on this issue has emerged in Cameroon. Statistics suggests that as many as "one in three" girls in Cameroon have experienced this practice, with an estimate of about 1.3 million girls. ${ }^{25}$ Breast ironing is a harmful practice against girls in the early stages of puberty. Often justified by the desire to prevent unsolicited male attention and curb promiscuity, breast ironing is a form of violence that finds expression within close family spaces and is conceived as good for the girl-child. The practice is often carried out by mothers on their daughters or close female relatives of survivors. ${ }^{26}$ The practice involves the use of objects such as pestles, spatulas or heated wooden spoons to prevent breast tissues from budding. Besides having serious psychosocial impacts, this practice also has an impact on the physical health and wellbeing of girls. ${ }^{27}$ From this harmful practice, girls are at risk of tissue damage and infection. There have been reports of girls fleeing from their homes and places of habitual residence due to this practice and, in certain situations, being further exposed to other forms of gender-based violence. ${ }^{28}$

Another prevalent form of harmful practice from which a connection may be drawn to internal displacement, is the sexual servitude of young girls in some parts of West Africa, specifically Ghana, Togo and Benin. ${ }^{29}$ In Ghana, this harmful practice, known as trokosi, involves offering young girls to shrines as compensation for criminal offences from family members. This practice is

23 K Almond "They escaped child marriage: Now they're speaking out" (22 December 2017) $\mathrm{CNN}$; "Resistance continues to ending child marriage in northern Nigeria" (22 March 2018) Voice of America; A Nzouankeu "Standing up for themselves: Nigerian girls refuse child marriage" (10 July 2019) Voice of America.

24 NV Pemunta "The social context of breast ironing in Cameroon" (2016) 3/4 Athens Journal of Health 335; T Bradley "Breast ironing is a harmful practice to young girls that isn't getting sufficient attention" (8 May 2019) Quartz Africa.

25 T Bradley "Breast ironing: A harmful practice that doesn't get sufficient attention" (2 May 2019) The Conversation.

26 Ibid.

27 I Lazareva "Breast-ironing: UK government vows to tackle abusive practice" (13 February 2019) The Guardian.

28 S Tetchiada "Cameroon: 'Breast-ironing' of young girls, a harmful custom" (13 June 2006) Women Living Under Moslem Laws, available at: < http://www.wluml.org/node/4129> (last accessed 20 January 2021).

29 AS Bilyeu "Trokosi - the practice of sexual slavery in Ghana: Religious and cultural freedom vs human rights” (1999) 9/2 Indiana International and Comparative Law Review 457; V Mistiaen "Virgin wives of the fetish gods: Ghana's trokosi tradition" (4 October 2013) Reuters; MA Klein Historical Dictionary of Slavery and Abolition (2014, Rowan \& Littlefield) at 370; $\mathrm{AB}$ Boaten "The Trokosi system in Ghana: Discrimination against women and children" in A Rwomire (ed) African Women and Children: Crisis and Response (2001, Praeger) 91; A Akonor "Trokosi: Young girls and women still in captivity years after law abolishing practice" (28 October 2019) Ghana Business News. 
also prevalent among some societies in South Sudan..$^{30}$ In this context, girls are offered to the families of victims of criminal activities in a practice known as girl compensation. ${ }^{31}$ The trokosi culture has affected "between 4,000 and 6,000 women and children" in Ghana alone. ${ }^{32}$ There have been occasions where girls flee this practice. However, this has often come with serious consequences, given the narrative associated with this form of practice. According to Gillard, "[g]irls who do try and escape and return to the village of their families are forcefully returned, as there is a penalty of fine (imposed on them by the fetish priests or elders of the villages) if they help the escapee". ${ }^{33}$

With the existence of internal displacement due to harmful practices, the specific recognition of this root cause in the Kampala Convention is significant. The next section examines protection for persons internally displaced by harmful practices, within the context of the Kampala Convention.

\section{PROTECTION OF PERSONS INTERNALLY DISPLACED BY HARMFUL PRACTICES}

From the outset, it is imperative to emphasize that the prohibition of harmful practices as a root cause of internal displacement is absolute. By implication, there can be no ground on which displacement for harmful practices may be justified in international $\mathrm{law}^{34}$ and article 4(4)(e) of the Kampala Convention is clear on this point. As such, a necessary starting point for understanding protection for persons internally displaced by harmful practices is prevention of this root cause of internal displacement. However, it is relevant to ask how internal displacement due to harmful practices should be prevented. In answering this question, it is relevant to examine other normative instruments that also explicitly prohibit harmful practices within the African human rights system.

Article 5 of the Maputo Protocol explicitly prohibits harmful practices and requires states to "condemn all forms of harmful practices which negatively affect the human rights of women and which are contrary to recognized international standards". Moreover, states are also required to take measures to eliminate this practice. ${ }^{35}$ Similarly, article 21 of the African Charter on the Rights and Welfare of the Child (African Children's Charter) ${ }^{36}$ requires states to ensure protection against harmful social and cultural practices that are

30 M Gathigah "South Sudanese girls given away as 'blood money" (10 July 2015) Inter Press Service.

31 Ibid.

32 Mistiaen "Virgin wives of the fetish gods", above at note 29.

33 LM Gillard Trokosi: Slave of the Gods (2010, Xulon Press) at 14.

34 Both CEDAW and the CRC reinforce the explicit prohibition of harmful practices. See Joint General Recommendation No 31 / General Comment No 18, above at note 4, para 10.

35 Maputo Protocol, art 5.

36 African Charter on the Rights and Welfare of the Child (1990). 
prejudicial to the rights of the child. An obligation on states in this regard is to "take all appropriate measures to eliminate" this practice. ${ }^{37}$ The Joint General Comment of the African Commission on Human and Peoples' Rights (African Commission) and of the African Committee of Experts on the Rights and Welfare of the Child on Ending Child Marriage, explained the nature of state obligations in the context of article 21 of the African Children's Charter. ${ }^{38}$ Drawing on this provision, measures include legislative, institutional and other steps to address the primary causes of these harmful practices. In the context of child marriage, for instance, this includes addressing poverty, gender inequality and discrimination. Given the fact that harmful practices are also prevalent due to deep-seated traditions and cultures, other measures extend to awareness-raising and the promotion of roles of faith-based and traditional mechanisms that have the capacity to influence outcomes.

However, where displacement occurs, what obligations are specifically placed on states within the context of protecting persons displaced by harmful practices? The Kampala Convention sets out specific obligations with respect to protection, assistance and durable solutions and, generally, these provisions will apply. However, it is useful to highlight certain obligations that are integral to the protection of persons affected by harmful practices. Article 9(2)(d) of the Kampala Convention requires states to ensure that psychosocial support is provided for "victims of sexual and other related abuses". Operationally, the Inter-Agency Standing Committee Guidelines on Mental Health and Psychosocial Support in Emergency Settings offer guidance emphasizing the pertinence of "a layered system of complementary supports that meets the needs of different groups". ${ }^{39}$ Participation is important to ensure that a topbottom approach is not adopted and that discriminatory practices are not reinforced. Another important aspect to fostering protection relates to regulating non-state actors, specifically private individuals given the fact that they are often perpetuators of this form of displacement. Article 3(h) of the Kampala Convention require states to ensure that non-state actors are held accountable where they carry out arbitrary displacement.

While the extent of the state's responsibility for the acts of non-state actors is not explicit in the Kampala Convention, states are responsible under international law for acts of non-state actors where they exercise control over those actors. ${ }^{40}$ However, in the absence of overall or effective control, international human rights law further recognizes another dimension to responsibility,

37 Id, art 21(1).

38 Joint General Comment of the African Commission and of the African Committee of Experts on the Rights and Welfare of the Child on Ending Child Marriage (2017) at 13-24.

39 See Inter-Agency Standing Committee Guidelines on Mental Health and Psychosocial Support in Emergency Settings (2007) at 11-12.

40 Prosecutor $v$ Duško Tadić appeal judgment (15 July 1999), para 131; Case Concerning Application of the Convention on the Prevention and Punishment of the Crime of Genocide (Bosnia and Herzegovina $v$ Serbia and Montenegro) judgment (26 February 2007). 
notably where a state fails to exercise due diligence. A state's obligation to ensure due diligence requires the state to establish mechanisms to ensure that non-state actors do not violate human rights and to take proactive measures where such violation occurs. ${ }^{41}$ In Zimbabwe Human Rights NGO Forum $v$ Zimbabwe, the African Commission emphasized that the "doctrine of due diligence requires the State to 'organize the governmental apparatus, and in general, all the structures through which public power is exercised, so that they are capable of juridically ensuring the free and full enjoyment of human rights"'.42 This implies the need for interactive governance in ensuring accountability, given the fact that fostering due diligence in the furtherance of human rights requires a multisectoral approach. For instance, in relation to $\mathrm{FGM} / \mathrm{C}$ or child marriage, this may involve the security, health, education and justice sectors. In General Comment No 5 on the African Charter on Human and Peoples' Rights on the Right to Freedom of Movement and Residence, the African Commission also emphasized this obligation as requiring states to take measures that "prevent infringements, investigate allegations, prosecute perpetrators and punish violations by non-state actors". ${ }^{43}$ With respect to a harmful practice such as FGM/C, preventing infringement by non-state actors will require, for instance, that the socio-cultural contexts that often sponsor the perpetration of such practices are addressed through sustained advocacy and deliberate campaigns. Moreover, measures need to be taken early to combat these practices through criminal legislation and collaboration with relevant stakeholders at various governance levels, including communities. There is also need for massive support for rights-based organizations working to prevent these practices. The duty to investigate requires that structural measures be established to ascertain violations or threats of such violations. This may require setting up community-based monitors that may also report threats of such practices. Moreover, it is important that civil society organizations working to address such harmful practices, including child marriage or FGM/C, are also included in this process. The duty to prosecute perpetrators and punish violations requires effective justice mechanisms. These must exist through formal and informal structures. However, it is important that an approach that puts survivors at the centre of justice paradigms is taken into account. Evidently, this will require that informal justice systems that absolve perpetrators of responsibility are reformed to align with the need for accountability.

Having examined the extent of the normative provision, the next section examines how protection and assistance to IDPs should be advanced within the institutional framework of the Kampala Convention.

41 Comm 245/02, Zimbabwe Human Rights NGO Forum v Zimbabwe (2006), para 147.

42 Ibid.

43 General Comment No 5 on the African Charter on Human and Peoples' Rights: The Right to Freedom of Movement and Residence (Article 12(1)) (2019), para 40. 


\section{REALISING PROTECTION FOR PERSONS INTERNALLY DISPLACED BY HARMFUL PRACTICES}

From an institutional standpoint, the Kampala Convention is emphatic on fostering compliance with its obligations through specific institutions recognized in article 14 of the Kampala Convention, notably the Conference of State Parties to the Kampala Convention (Conference), the African Commission and the African Peer Review Mechanism (APRM). The Conference is the primary institution saddled with implementing obligations in the Kampala Convention. ${ }^{4}$ Comprising states that have ratified the Kampala Convention, ${ }^{45}$ the Conference is an important forum for the exchange of viewpoints and sharing of ideas on furthering protection for and assistance to IDPs. The Conference's first meeting was held in Harare, Zimbabwe when an action plan on the Kampala Convention was adopted. ${ }^{46}$ Much of the discussion at this meeting was a reflection on national law and policy, relevant to IDP issues in countries such as Malawi, Nigeria, Rwanda and Zimbabwe. Significantly, the Conference emphasised the need for states to utilize the Kampala Convention as an effective regional response.

Given the pertinence of the Conference as the regional institution comprising parties to the Kampala Convention, it provides an important forum for addressing harmful practices. One of the ways through which the Conference may address harmful practices is through developing a regional action plan on displacement induced by harmful practices. This action plan should guide states on moving from norm to implementation in addressing this issue, specifically given the prevalence of harmful practices and the limited attention to this root cause of internal displacement.

Another important institution is the African Commission, which is the principal regional body for advancing human rights in Africa. In view of its broad mandate in article 45 of the African Charter on Human and Peoples' Rights (African Charter) and specifically its mention in article 14(4) of the Kampala Convention, the African Commission has a role to play in fostering protection at the regional level. Under article 14(4) of the Kampala Convention, states are required to incorporate in their state reports to the African Commission (in line with article 62 of the African Charter) measures taken to implement the Kampala Convention. To ensure that states are able to report on this

44 Kampala Convention, art 14(1).

45 As at January 2021, 31 states have ratified the Kampala Convention: AU "List of countries which have signed, ratified / acceded to the African Union Convention for the Protection and Assistance of Internally Displaced Persons in Africa (Kampala Convention)", available at: <https://au.int/sites/default/files/treaties/36846-sl-AFRICAN\%20UNION\%20CONVEN TION\%20FOR\%20THE\%20PROTECTION\%20AND\%20ASSISTANCE\%20OF\%20INTERNALLY \%20DISPLACED\%20PERSONS\%20IN\%20AFRICA\%20\%28KAMPALA\%20CONVENTION\%29. pdf> (last accessed 15 January 2021).

46 Conference "Harare plan of action for the implementation of the Kampala Convention (2017-2022)” (2017). 
obligation, it is crucial that the African Commission revise its state reporting guidelines specifically to include internal displacement as an issue on which states need to report. The reporting guideline on the Maputo Protocol requires states to include specific information with respect to practices harmful to women, including FGM within the context of protecting women from violence. ${ }^{47}$ This provision is significant and indeed may be used to reinforce the prevention of harmful practices within a displacement context. However, to ensure that internal displacement is highlighted and various root causes of internal displacement are underscored, the African Commission should also develop specific reporting guidance on internal displacement. This could be through a range of options. First, it could be through the formation of a specific reporting guideline on harmful practices as a root cause of internal displacement, specifically in respect of article 4(4)(e) of the Kampala Convention. Secondly, it could be through a comprehensive guideline for reporting on internal displacement leveraging on the Kampala Convention, which also includes harmful practices. Thirdly, there could be a set of indicative questions to state parties in respect of the Kampala Convention more generally or harmful practices more specifically. There are evidently existing practices that justify these options. For instance, the African Commission has previously developed guidelines for reporting specifically on the Maputo Protocol. It has also developed guidelines on particular articles of the African Charter, specifically articles 21 and 24 relating to the issue of extractive industries, human rights and the environment. ${ }^{48}$ Moreover, it has also developed indicative questions with respect to article 5 of the African Charter, which focuses on the prohibition of torture and cruel, inhuman and degrading treatment. ${ }^{49}$ Any of these approaches will highlight the issue of internal displacement and, specifically, harmful practices.

The APRM is a regional peer review system, similar to the Universal Peer Review in terms of its voluntary nature but with a broad objective of fostering respect for democratic governance and human rights in Africa. As part of the APRM process, states are required to report on measures taken to actualize democratic governance, development and human rights within national contexts. For this purpose, the APRM Secretariat has developed a questionnaire to assist states with this process. While the questionnaire broadly incorporates

47 AU "Guidelines for state reporting under the Protocol to the African Charter on Human and Peoples' Rights on the Rights of Women in Africa”, available at: <https://www.achpr. org/public/Document/file/English/Guidelines\%20on\%20State\%20Reporting\%20under\%20 the\%20Maputo\%20Protocol_2.pdf> (last accessed 15 January 2021).

48 AU "State reporting guidelines and principles on article 21 and 24 of the African Charter relating to extractive industries, human rights and the environment" (2017).

49 AU "State periodic reporting under article 62 of the African Charter on Human and Peoples' Rights: Indicative questions to state parties in respect of article 5 of the African Charter", available at: <https://www.achpr.org/public/Document/file/English/ Indicative $\% 20$ Questions $\% 20$ to $\% 20$ State $\% 20$ Parties $\% 20$ in $\% 20$ respect $\% 20$ of $\% 20$ Article $\% 205 \%$ 20of\%20the\%20Afr....pdf> (last accessed 15 January 2021). 
the Kampala Convention in terms of ratification and domestication, ${ }^{50}$ it does not specifically detail the content of the treaty, to ensure that states report explicitly on specific issues. In fostering compliance with the Kampala Convention and ensuring that states report on the specific issue of displacement induced by harmful practices, the APRM should revise its questionnaire to include the need for states to report on internal displacement, including displacement induced by harmful practices, when they prepare for country review.

\section{CONCLUSION}

Over the last decade, significant studies have emerged on the Kampala Convention as the regional law on protecting and assisting IDPs. The Kampala Convention elaborates a binding framework that addresses protection gaps within existing internal displacement mechanisms while being specific to the African context. While drawing normative strength from the Guiding Principles, the Kampala Convention carves its own path by being context-specific to the African region. One of the ways through which this is done is in recognizing harmful practices as a root cause of internal displacement.

This article examined this specific issue, considering evidence on the practice and its connection with internal displacement. In ensuring protection, this article argued that a starting point must be the prevention of harmful practices through the formation of normative and institutional structures where these measures do not exist. Moreover, other measures need to be adopted to address the root cause of such harmful practices, raise awareness and promote the roles of faith-based and traditional mechanisms. However, where displacement occurs, it is imperative that protection, humanitarian assistance and durable solutions are sought. Moreover, specific protection such as psychosocial support and the participation of those displaced in developing sustainable solutions to the displacement situation must be advanced.

It is imperative that measures for the accountability of non-state actors be established in furtherance of states' due diligence obligation. Article 3(h) of the Kampala Convention is emphatic on this in emphasizing the need for states to foster the accountability of non-state actors, including private actors. However, in implementing the obligation, specific regional institutions have a crucial role in light of the specific obligation in article 14 of the Kampala Convention. This article argued that the Conference may adopt a regional action plan on ending displacement induced by harmful practices. Moreover, the African Commission should revise its state reporting guidelines to ensure that issues of internal displacement and, specifically, harmful

50 APRM "Revised country self-assessment questionnaire for the African Peer Review Mechanism", available at: <https://www.aprm-au.org/wp-content/uploads/2014/11/Co untry-Self-Assessment-Questionnair.pdf> (last accessed 15 January 2021). 
practices are captured. This article has proposed a range of options in this regard. The African Commission could: adopt a specific reporting guideline on harmful practices; develop a comprehensive reporting guideline on internal displacement, specifically highlighting harmful practices; or develop indicative questions on the Kampala Convention more generally or harmful practices more specifically. Likewise, the APRM should revise its state reporting questionnaire to ensure that countries under review can be reviewed on this root cause of internal displacement.

\section{CONFLICTS OF INTEREST}

None 